\title{
Organic course of a disease of winter rape depending on periods of sowing and microfertilizers
}

Savchuk Yu.

postgraduate student ${ }^{*}$

National University of life and environmental Sciences of Ukraine

\section{*doctor of agricultural sciences, professor Antonenko O. - supervisor}

The purpose. To study influence of periods of sowing and microfertilizers on course of a disease of winter rape. Methods. Field, visual, settlement-mathematical. In researches they used cultivars of winter rape Snizhna Koroleva, Andromeda, Vesuviy and microfertilizer Vuksal microplant, Terios and Askofol. Results. It is determined that application of microfertilizers did not have significant influence upon course of a disease. Affection of cultivars of winter rape depended mainly on periods of sowing and properties of a cultivar. Conclusions. Cultivars of winter rape Vesuviy and Snizhna Koroleva were rather stable against false mildew in an early period of sowing. Comparative resistance against phomosis and alternaria was manifested by these cultivars in optimum and late periods of sowing. In an early period of sowing microfertilizer Vuksal microplant was highly effective against sicknesses, while in optimum and late period of sowing - Terios and Askofol.

Key words: winter rape, sickness, periods of sowing, microfertilizer.

The study of the most common diseases on winter rape, their development depending on sowing dates (early, optimum and late) [1, 2, 7]. Restrictions diseases by seed treatment with micronutrients (Wuxal Microplant, Terios, Askophol) [3, 6].

The most common diseases of winter rapeseed are downy mildew, phoma, alternaria. The development of these diseases depends on many factors. The main ones are weather conditions, the biology of the pathogen and the host plant, their varietal characteristics $[2,5,8,9,10]$.

Goal of the research. To justify measures to restrict the development of the most dangerous diseases by application of micronutrients and the influence of terms of sowing of winter rape varieties.

Objectives: to assess the development of diseases on varieties of winter oilseed rape depending on sowing time. To study the effect of micronutrients on limiting the development of these diseases.

The methodology of research. Our research was included varieties of winter rape the Snihova Koroleva, Andromeda and Vesuviy, which pass the state test. We studied the sowing time: early (11, August); the optimal (21, August), late (31, August). Sowing was carried out on experimental plots with a size of $60 \mathrm{~m}^{2}$ in a 3-fold repetition [4]. Before sowing the seeds treated by fertilizer (Wuxal Microplant, Terios and Askophol). Wuxal Micropland - highly concentrated suspension of micronutrients designed for foliar feeding of intensive cultivation. Wuxal Terios is a suspension fertilizer for seed treatment in nitrogen, phosphorus, copper, manganese, molybdenum and zinc. Wuxal Askophol - a highly concentrated suspension extradited from brown seaweed Ascophyllum nodosum. The studies were conducted in separated subdivision of NULES "Agronomic research station". The soil of experimental field is black soil humus.

The results of the research. By results of researches it was established that the development of the diseases the application of micronutrients of considerable influence had not. The infestation of varieties of winter rape diseases in the vast majority depended on sowing dates and varieties. According to the data of the tables is relatively resistant varieties of winter rape against downy mildew was Vesuviy, which the lesion was $0 \%$ in the early and optimal sowing time; the later $-3.1 \%$ (control). Variety the snihova koroleva on this disease at the optimum sowing date also had lesions $0 \%$. Early and late sowing destruction downy mildew were respectively $3.5 \%$ and $2,1 \%$. According to resistant against downy mildew turned out to be a kind of 
rape of Andromeda. Relatively phomosis, at an early period of sowing the defeat of the varieties ranged from $18.6 \%$ to $22.5 \%$. (table. $1,2,3$ ).

Table 1. Vulnerability to diseases of varieties of winter rapeseed (early sowing date).

\begin{tabular}{|c|c|c|c|c|}
\hline \multirow{2}{*}{ Variety } & \multirow{2}{*}{ Microfertilizer } & \multicolumn{3}{|c|}{ Disease, $\%$} \\
\hline & & Downy mildew & Plant stem & Alternaria \\
\hline I & II & III & IV & $\mathbf{V}$ \\
\hline Snihova Koroleva & \multirow{3}{*}{ Control } & 3,5 & 20,8 & 5,8 \\
\hline Andromeda & & 0,5 & 18,6 & 25,0 \\
\hline Vesuvius & & 0,0 & 22,5 & 20,4 \\
\hline Snihova Koroleva & \multirow{3}{*}{ Microplant } & 1,5 & 10,2 & 6,6 \\
\hline Andromeda & & 0,1 & 10,0 & 16,6 \\
\hline Vesuvius & & 0,0 & 8,0 & 10,0 \\
\hline 1 & II & III & IV & $\mathrm{V}$ \\
\hline Snihova Koroleva & \multirow{3}{*}{ Ascophol } & 2,0 & 15,1 & 5,8 \\
\hline Andromeda & & 0,0 & 5,6 & 10,0 \\
\hline Vesuvius & & 0,0 & 10,0 & 12,0 \\
\hline Snihova Koroleva & \multirow{3}{*}{ Terios } & 2,8 & 10,0 & 6,5 \\
\hline Andromeda & & 0,0 & 10,0 & 15,0 \\
\hline Vesuvius & & 0,0 & 20,0 & 15,4 \\
\hline
\end{tabular}

At optimum and late sowing dates defeat was 45 times lower, this situation destruction is associated with the biological properties of the pathogen, as well as the phase of development of the varieties (table. 2, 3).

Table 2. Vulnerability to diseases of varieties of winter rapeseed (optimum sowing time).

\begin{tabular}{|c|c|c|c|c|}
\hline \multirow[b]{2}{*}{ Variety } & \multirow[b]{2}{*}{ Microfertilizer } & \multicolumn{3}{|c|}{ Disease, \% } \\
\hline & & Downy mildew & $\begin{array}{l}\text { Plant } \\
\text { stem }\end{array}$ & Alternaria \\
\hline $\mathrm{T}$ & II & III & IV & $\mathbf{V}$ \\
\hline Snihova Koroleva & \multirow{3}{*}{ Microplant } & 0,5 & 2,4 & 3,1 \\
\hline Andromeda & & 0,1 & 0,8 & 1,1 \\
\hline Vesuviy & & 2,2 & 3,1 & 2,8 \\
\hline Snihova Koroleva & Control & 0,0 & 5,2 & 6,4 \\
\hline $\mathrm{I}$ & II & III & IV & $\mathrm{V}$ \\
\hline Andromeda & \multirow{5}{*}{ Terios } & 0,0 & 2,0 & 3,6 \\
\hline Vesuviy & & 0,0 & 0,8 & 3,0 \\
\hline Snihova Koroleva & & 1,2 & 1,2 & 1,2 \\
\hline Andromeda & & 0,5 & 2,2 & 4,1 \\
\hline Vesuvius & & 0,0 & 0,4 & 1,0 \\
\hline Snihova Koroleva & \multirow{3}{*}{ Ascophol } & 1,2 & 0,8 & 0,8 \\
\hline Andromeda & & 0,8 & 1,3 & 2,8 \\
\hline Vesuviy & & 2,1 & 3,3 & 3,8 \\
\hline
\end{tabular}

Lose varieties of winter rape the Snihova Koroleva by Plant stem at all dates of sowing were carried stable. At the early sowing date maximum destruction by Alternaria varieties Vesuviy and Andromeda respectively amounted to $20.4 \%$ and $25,0 \%$ (control variant) (table. 1).

Table 3. Susceptibility of diseases of winter rapeseed varieties (late sowing date).

\begin{tabular}{|c|c|c|c|c|}
\hline \multirow[b]{2}{*}{ Variety } & \multirow[b]{2}{*}{ Microfertilizer } & \multicolumn{3}{|c|}{ Disease, \% } \\
\hline & & Downy mildew & $\begin{array}{l}\text { Plant } \\
\text { stem }\end{array}$ & Alternaria \\
\hline$T$ & II & III & IV & $\mathbf{V}$ \\
\hline Snihova Koroleva & \multirow{3}{*}{ Ascophol } & 1,0 & 0,3 & 2,2 \\
\hline Andromeda & & 0,6 & 0,5 & 1,1 \\
\hline Vesuviy & & 1,1 & 0,9 & 0,6 \\
\hline Snihova Koroleva & \multirow{3}{*}{ Terios } & 0,0 & 0,3 & 0,5 \\
\hline Andromeda & & 0,0 & 0,3 & 1,3 \\
\hline Vesuviy & & 0,1 & 0,5 & 0,5 \\
\hline Snihova Koroleva & \multirow{3}{*}{ Control } & 1,2 & 5,1 & 3,3 \\
\hline Andromeda & & 0,5 & 1,1 & 2,3 \\
\hline Vesuviy & & 3,1 & 2,2 & 3,0 \\
\hline Snihova Koroleva & \multirow{3}{*}{ Microplant } & 0,8 & 0,0 & 1,2 \\
\hline Andromeda & & 0,0 & 0,3 & 0,1 \\
\hline Vesuviy & & 2,0 & 1,8 & 2,6 \\
\hline
\end{tabular}


The application of microfertilizer, however, shows that, depending on sowing time restricts the development of diseases on varieties of winter rapeseed. Thus, the use of Wuxal Microplant, Askopol and Terios in optimum and late sowing, susceptibility of varieties by plant stem and alternaria in $1.5-2$ times was lower relative to the control. At the early sowing date application of microfertilizer at $1.0-1.5$ times reduced the downy mildew. In early sowing time a high efficacy against diseases of oilseed rape was detected by Wuxal Micropland,on optimum and late sowing date - the Terios and Askopol.

\section{Conclusions}

The results of the conducted researches it is established:

1. At the early sowing time is relatively resistant to downy mildew was variety of Vesuviy and Snihova koroleva.

2. Relative resistance to plant stem and alternaria showed variety for optimum and late sowing date.

3. Early sowing, high effectiveness against diseases found Voxal Microplant, optimum and late - Terios and Askophol.

\section{References}

1. Agejchik V.V. Krestocvetnye kul'tury / V.V. Agejchik, E.N. Poloznjak // Integrirovannye sistemy zashhity sel'skohozjajstvennyh kul'tur ot vreditelej, boleznej i sornjakov: rekomendacii / Institut zashhity rastenij. — Mn.: Bel. nauka, 2005. - S. 219-229.

2. Andrusevich, M.P. Vlijanie srokov seva na urozhajnost' maslosemjan ozimogo rapsa / M.P. Andrusevich, F.F. Sedljar // Sel'skoe hozjajstvo - problemy i perspektivy: sbornik nauchn trudov. Grodno: UO «GGAU», $2009-$ T.1. - S. 21-28.

3. Antonenko O. F. Khvoroby ripaku. Shkaly vyznachennia imunnosti sortiv do naiposhyrenishykh ta yikh zastosuvannia v metodykakh otsinky / O. F. Antonenko // Zakhyst roslyn. - 2001. - № 12. - S. 14.

4. Dospekhov B.M. Metodyka polevoho opыta / Dospekhov B.M. - Kolos, 1985. - 351 s.

5. Makrushyn M.M. Nasinnytstvo (metodolohiia, teoriia, praktyka): pidruchnyk, vydannia druhe, dopovnene i pereroblene/ M.M. Makrushyn, le.M. Makrushyna. — Simferopol VD «Arial» 2012. — $564 \mathrm{~s}$.

6. Markov Y.L. Bolezny rapsa y metodb ykh ucheta / Y.L. Markov // Zashchyta rastenyi. — 1991. _ S. $55-60$.

7. Piljuk Ja.Je. Raps $\vee$ Belarusi (biologija, selekcija i tehnologija vozdelyvanija): monografija / Ja.Je. Piljuk. — Mn.: Biznesofset, 2007. — 240 s

8. Rekomendatsii z vyroshchuvannia ozymoho ripaku. / Abramyk M.I., Korzhan S.I., Kyforuk I.M., Stelmakh O.M., Chornyi H.D.- Ivano-Frankivsk, 2004. - $14 \mathrm{~s}$.

9. Sytnyk I.D. Alternarioz ripaku ta metody yoho otsinky / I.D. Sytnyk // Zakhyst roslyn. - 2002. v. 12. - S. 8-9.

10. Shpaar D. Raps y surepytsa. Vyrashchyvanye, uborka, khranenye y yspolzovanye. - K: 2012. 